\title{
An Accounting Perspective of Tax Amnesty in Indonesia
}

\author{
Euodia Shienny Natania \\ International Class of Management and Accounting Program (ICMAP) \\ Faculty of Economics and Business, Satya Wacana Christian University
}

\author{
Arthik Davianti \\ Department of Accounting, Faculty of Economics and Business \\ Satya Wacana Christian University
}

\begin{abstract}
Tax Amnesty involves Public Accountant, Government Accountant, and Internal Accountant. Their roles are primarily to give services that would increase the quality of financial information related to accounting or finance in examining the financial statement after getting additional fund or asset from a tax amnesty program. Due to the various parties involved in the program, there will be different new standards or policies designed by different institutions in managing tax amnesty. From an accounting perspective, Dewan Standard Akuntansi Keuangan (DSAK), Financial Accounting Standards Board released standard for tax amnesty in the additional asset and fund from repatriation in the form of either bond or stake named Pernyataan Standar Akuntansi Keuangan (PSAK) 70, Financial Accounting Standards 70. However, the new standard is expected not to distress the taxpayers because it also becomes the consideration for taxpayers whether they will participate in the tax amnesty program or not. Therefore, it needs a Public Accountant or Internal Accountant to produce a proper financial statement that already contains adequate accounting method.
\end{abstract}

Keywords: Tax Amnesty, Public Accountant, Government Accountant, Financial Information, Financial Statement

\section{Introduction}

In 2016, the Indonesian government issued a new tax program, which is tax amnesty. The application of tax amnesty was driven by the global economic downturn, due to the decreasing trading activity, followed by the increasing prices of the export-import activity. Also, the tax ratio in Indonesia is considered to be too low compared to other neighboring countries. However, as anticipated, the implementation of tax amnesty requires global information disclosures, particularly repatriation fund from overseas investments. For example, in addition to banks in Indonesia, Singapore is one of a place to invest. According to The Jakarta Post (2016), more than a half of Singapore's economy is supported by Indonesian business people with an estimation of US $\$ 200$ billion in private banking assets and 40 percent of the island's total private banking assets. Such investments are to be disclosed in the tax amnesty program. This particular disclosure as in Automatic Exchange of Information (AEoI) will start in 2018 and also the revision of banking regulation to disclose data for taxation. AEoI is already 
agreed in the Group of Twenty's (G-20) meeting last February in China (Merah Putih Bisnis, 2016). After arrived in this situation, taxpayers cannot conceal their asset anymore from the tax authority. The disclosures will include economic proxy war such as assets protection scheme and international planning that will inflict country financial loss (Aliandu, 2016). The Indonesian government also considered tax amnesty as a way out to solve its economic problems. Therefore, the underlying perception for that consideration is that tax amnesty is expected to gain more funds from tax based on disclosing the repatriation fund from overseas investments.

Tax amnesty has been one of the strategies to increase tax collection by the government. Thirty-eight countries around the world have already applied the tax amnesty; fourteen of those countries was recently implemented the tax amnesty. These countries are Argentina, Trinidad \& Tobago, Thailand, Honduras, Indonesia, South Korea, Fiji, Pakistan, and Gibraltar. Five other countries implemented tax amnesty, specifically in repatriation fund from overseas investments are Israel, Malaysia, Russia, Brazil, and India (Maskur, 2016). Tax amnesty is a challenging strategy in increasing tax inflow as there are only three out of the listed thirty-eight countries, was regarded as successful in implementing this program. These countries are India, Italia, and South Africa. Therefore, the implementation of tax amnesty could face potential failure or success. This concern leads to a realization that a tax amnesty program could raise public concerns. Further, tax amnesty, to some extent, is considered as a new terror, especially to entrepreneurs and companies. As a result, they are reluctant to comply with tax amnesty, also do not want to pay the appropriate nominal by hiding some of their wealth.

The implementation of the tax amnesty in Indonesia involves government agencies and banks which are Otoritas Jasa Keuangan (OJK), Financial Services Authority as the supervisor, Center for Reform in Economics (Core) Indonesia Research and Institute for Development and Finance (INDEF) as the third party for monitoring the government. Other government agencies include Badan Koordinasi Penanaman Modal (BKPM), Capital Investment Coordinating Board, and Badan Usaha Milik Negara (BUMN), Indonesian State-Owned Enterprises as the party that will issue bonds for repatriation fund from overseas investments. Banks are a temporary place to accommodate repatriation fund from foreign investments and the repatriation fund as an investment in banking product.

Table 1. Composition of Wealth Based on Received Surat Pernyataan Harta (SPH), Asset Declaration Letter per October 6, 2016

\begin{tabular}{lc}
\hline Wealth composition based on received SPH & Amount \\
\hline Repatriation & $\operatorname{Rp~139~T~}$ \\
Declaration Overseas & $\operatorname{Rp~968~T~}$ \\
Declaration of Domestic & $\operatorname{Rp~2,621~T~}$ \\
Total & Rp 3,728 T \\
\hline
\end{tabular}


Table 2. Composition of Wealth Realization Based on Received Surat Setoran Pajak (SSP), Tax Payment Slip as per October 6, 2016

\begin{tabular}{ll}
\hline Wealth realization composition based on received SSP & Amount \\
\hline Payment of Redemption Money & Rp 93.8 T \\
Payment of Preliminary Evidence & Rp 364 B \\
Payment of Arrears & Rp 3.06 T \\
Total & Rp 97.3 T \\
\hline
\end{tabular}

Source: www.pajak.go.id (Direktorat Jenderal Pajak, 2016)

Table 1 shows how the government has recorded the totaling declared assets as Rp3,728 trillion from the tax amnesty program. Meanwhile, in Table 2, it can be seen that the government has pocketed Rp93.8 trillion in redemption money. Meanwhile, the repatriated funds have reached Rp139 trillion (Direktorat Jenderal Pajak, 2016). According to Cabinet Secretary, Pramono Anung, most of the Rp500 trillion assets have come from business people who own significant assets. Pramono is optimistic to see more big fish joining the tax pardon (Amindoni, 2016).

Tax Amnesty involves Public Accountant, Government Accountant, and Internal Accountant. Their roles are primarily to give services that would increase the quality of financial information related to accounting or finance in examining the financial statement after getting additional fund or asset from a tax amnesty program. Due to the various parties involved in the program, there will be different new standards or policies designed by different institutions in managing tax amnesty. From an accounting perspective, Dewan Standard Akuntansi Keuangan (DSAK), Financial Accounting Standards Board released standard for tax amnesty in the additional asset and fund from repatriation in the form of either bond or stake named Pernyataan Standar Akuntansi Keuangan (PSAK) 70, Financial Accounting Standards 70. However, the new standard is expected not to distress the taxpayers because it also becomes the consideration for taxpayers whether they will participate in the tax amnesty program or not. Therefore, it needs a Public
Accountant or Internal Accountant to produce a proper financial statement that already contains adequate accounting method.

In the background above, this study analyzes the accounting perspective on tax amnesty program in Indonesia. The purposes of the study are to describe and to review the tax amnesty program from an accounting perspective. It is a need to see tax amnesty from an accounting perspective because as the practitioners of accounting, accounting measurement in tax is critical moreover for the tax amnesty, which is a new program. With the purpose mentioned above, this study is expected to have a contribution for any related parties. For the practical benefit, this research prospected as a reference for people for knowing about the relationship of accounting perspective in tax amnesty. For the theoretical advantage of this study is prospected as a contribution to science and as a reference for the next study with a similar topic in the future since there is no previous study before in Indonesia about accounting perspective in tax amnesty.

\section{Literature Review}

\section{Tax Concept}

Tax is the primary source of funds for country's income. The government utilizes income from tax to build the country in various aspects such as infrastructure, telecommunication, and 
education also as the country's expenditure. Tax is a compulsory contribution to the country owned by individuals or business entities that are enforceable under the Act, by not getting the rewards directly and used for the country for the welfare of the people (Direktorat Jenderal Pajak, 2012). Accordingly, paying taxes is not only as of the obligation to taxpayers but also for the right to participate in financing and developing the country actively.

The tax ratio is used to assess the level of compliance of the payment of the taxes by the people in the country. The tax ratio is the ratio between the amount of tax revenue compared to the Gross Domestic Product (GDP) (Ortax, 2016). Tax revenue income in Indonesia last year (2015) is only reached Rp598 trillion or about $46 \%$ from Anggaran Pendapatan dan Belanja Negara Perubahan (APBNP) 2015, Revised State Budget 2015's target (BBC Indonesia, 2016). In 2016, the tax revenue target was reaching Rp1,355 trillion. Per the last first semester, tax revenue was stood at Rp458.2 trillion, which was only $33.8 \%$ of the tax revenue target because of the economic downturn (Sawitri, 2016). The government launched the tax amnesty program to help achieve the tax revenue target; set the number of declared assets reaching $\mathrm{Rp} 4,000$ trillion, repatriation of funds amounting to Rp1,000 trillion, and the redemption money into the country treasury amounted to Rp165 trillion as of the target for tax amnesty program (Fajriah, 2016).

The implementation of tax amnesty 1964 is based on the Penetapan Presiden Nomor 5 Tahun 1964 (Presidential Decree Number 5 the Year 1964) which is started from September 9, 1964, and it has a due date until August 17, 1965 (Katawarta, 2016). The redemption money rates were divided into two, which are $5 \%$ and $10 \%$ for a whole year of amnesty. The punishment was fined $400 \%$ if not comply with the rules. Unfortunately, the tax amnesty 1964 was failed because of the lack of socialization as well as the lousy taxation system. The
The tax amnesty program is the tax collection strategy to meet the government's tax revenue target based on government regulation.

The taxation system that applies in Indonesia is the self-assessment system. Self-assessment system is a system where individual or business entities are responsible for recording, reporting and made payment of tax liabilities (Direktorat Jenderal Pajak 2012), Tax amnesty is one part application of this tax system. The tax system is also another reason why the Government needs to run the tax amnesty program because self-assessment taxation system sometimes made some tax liabilities are not similar to the actual number. Individuals, as well as business entities, tend to decrease the tax liabilities amount by covering the total net profit (increasing expense).

Before the self-assessment system, the taxation system in Indonesia is an official assessment. In this arrangement, the tax authorities determine, calculate, and set the amount of tax payable. In Indonesia, the first tax amnesty that held in 1964 was using formal assessment as the taxation system until the second tax amnesty in 1984 . The transition happened from changed the official assessment to the self-assessment until nowadays. However, the results were still unsatisfactory; therefore, the government launched another tax amnesty program.

government was held the second tax amnesty program in the year 1984 .

The tax amnesty in 1984 is based on the Penetapan Presiden Nomor 26 Tahun 1984 (Presidential Decree Number 26 the Year 1984) dated April 18, 1984, that valid until December 31, 1984 (Katawarta, 2016). This second tax amnesty was made Indonesian taxpayers experiencing the transition from official to self-assessment that becomes fixed taxation system nowadays. There were also two redemption money rates, which are $1 \%$ of taxpayers that are already entered the tax notice letter 
to Director General of Taxes and $10 \%$ of taxpayers that have not registered yet. This second program is also facing failure because taxation in that era was not encouraged by the government, and the fundamental taxation data was not as good as the taxation system, which was not adequate.

Table 3. Wealth Declared and Redemption Money (until September 28, 2016)

\begin{tabular}{cccc}
\hline \multirow{2}{*}{ Country } & \multirow{2}{*}{ Year } & Wealth Declared & Redemption Money \\
\cline { 3 - 4 } & 2016 & $2,514 \mathrm{~T}$ & $81.1 \mathrm{~T}$ \\
Indonesia & 2009 & $1,179 \mathrm{~T}$ & $59 \mathrm{~T}$ \\
Italia & 2615 & $263 \mathrm{~T}$ & $19.7 \mathrm{~T}$ \\
Chili & $202 \mathrm{~T}$ & $17.7 \mathrm{~T}$ \\
Spain & 2012 & $115 \mathrm{~T}$ & $2.3 \mathrm{~T}$ \\
South Africa & 2003 & $66 \mathrm{~T}$ & $7.9 \mathrm{~T}$ \\
Australia & 2014 & $26 \mathrm{~T}$ & $4.1 \mathrm{~T}$ \\
Ireland & 1993 & &
\end{tabular}

Source: www.cita.or.id (Center for Indonesia Taxation Analysis, 2016)

After the government launched the tax amnesty program in 2016, it resulted in the most successful program to date for a better Indonesia's development. This program did not run as expected, because there were many disagreements about the implementation of the program, as previously experienced in 1964 and 1984. However, because it is considered to be no better alternative, the tax amnesty program was selected as the solution proposed by Luhut Binsar Pandjaitan, the Coordinating Minister for Maritime, according to Simbolon (2016). After proposed by Luhut, the next concept of tax amnesty was designed by Kantor Staf Presiden (KSP), Presidential Staff Office, the Office of the Vice President, and the World Bank (Indrawan, 2016).

\section{Tax Amnesty}

House of Representatives had announced tax amnesty law in Indonesia on June 28, 2016, and it is stated in Undangundang Nomor 11 Tahun 2016 (Laws Number 11 the Year 2016) about Tax Amnesty that will be valid till March 31, 2017 (BBC Indonesia, 2016). According to Direktorat Jenderal Pajak (2016), tax amnesty is forgiveness program granted by the government to taxpayers including the elimination of taxes that should be owed, the removal sanctions of tax administration as well as the removal of criminal penalties in the field of taxation on property acquired in 2015 that have not been reported in the tax return previously by setting off the whole owned tax arrears and pay the redemption money. About getting tax amnesty, there is also a consequence for taxpayers who join tax amnesty but have not revealed some of their wealth. This type of wealth that are not yet exposed after following the tax amnesty program will be calculated as additional income and will receive $200 \%$ of sanction.

As mentioned earlier in the introduction, tax amnesty was applied because there is world economic downturn especially from the decreasing trading activity and prices of the export commodity, enlarged budget deficit, manufacture decrease growth rate, and high infrastructure gap. As the consequences, there are subsequent impacts such as unemployment, poverty, and discrepancy between the poor \& the generous rich person that is increased. Tax amnesty is chosen as the source of investment that can 
improve Indonesia's economic wheels to solve some of the problems faced by the country. The investment is in the form of offshore assets or investment funds from abroad. The government attempted to withdraw Indonesians' overseas investments to be invested back in the country. This effort to pull investment back is known as repatriation.

The government lowered the redemption money rates, as there are three periods in joining tax amnesty which is September 30, 2016, December 31, 2016, and March 31, 2017, to attract more taxpayers to join tax amnesty program. Redemption money rates that must be paid according to Direktorat Jenderal Pajak (2016), Undang-undang Nomor 11 Tahun 2016 Bab IV Pasal 4 ayat 1-3, (Law Number 11 the Year 2016 Chapter IV Paragraph 4 article 1-3) are as follows (depending on the reporting of Letter of Request for Amnesty):

1. $2 \%-5 \%$ for those who have wealth inside the country and wealth outside the country that will be repatriating and investing in the country for a minimum of three years,

2. $4 \%-10 \%$ for those who have wealth outside the country that will not be repatriated,

3. $0.5 \%-2 \%$ for those who have income from the circulation of business started from Rp10 billion and more.

The amount of the redemption money can be obtained from the formula that is already determined by Direktorat Jenderal Pajak (2016), which is based on the tariff times net assets. Net assets are the difference between the additional assets that not yet reveal minus the liabilities that not yet expose related to the acquisition of other assets.

There are also many advantages of joining the tax amnesty program besides paying lower redemption money, incomplete (Direktorat Jenderal Pajak, 2016):
1. Elimination of taxes that should be owed,

2. The removal of sanctions of tax administration, as well as the elimination of criminal penalties in the field of taxation,

3. No assessment, preliminary evidence examination, and investigation,

4. Termination of the examination process, review of preliminary evidence, and the investigation,

5. Guarantees where the data confidential tax amnesty cannot be the basis of the examination and investigation of other criminal offenses, and

6. Income tax exemption related to the process behind the name of the property.

All taxpayers such as companies in business entities can take the advantages of the tax amnesty except for corporations under text investigation which has been completed or has received Pemberitahuan bahwa Hasil Penyidikan Sudah Lengkap (P-21). This exception also includes any investigations that are currently under the judicial process, and under any conviction of a crime in the field of taxation.

The wealth of Indonesian businesspeople spread all over the world. The tax office has identified 272 taxpayers out of 1,038 taxpayers owning the Nomor Pokok Wajib Pajak (NPWP), Taxpayer Identification Number listed in the Panama Paper that is a leak of documents posted by the International Consortium of Investigative Journalists (ICIJ) (Amindoni, 2016). The reports drove the Tax Office to retrieve the data on Indonesian taxpayers with offshore companies from Group of Twenty (G-20) countries, as that were around 6,500 Indonesian named on the list (Amindoni, 2016). Former Minister of Finance, Bambang Brodjonegoro said that the data from taxation about Indonesian businesspeople overseas investments is higher than Indonesian Gross Domestic Product (GDP) in 2016 which is around Rp11.400 billion (Prasetiyo, 2016). 
Consequently, it is expected that the amount of money Indonesians have resting overseas is incredibly high.

The fund is invested in overseas to avoid tax responsibilities. It is most likely to be invested by investors in tax haven countries. The most favorite country is British Virgin Island or Singapore (Prasetiyo, 2016). Furthermore, tax evasion strategy taken by taxpayers caused the tax ratio in Indonesia lower than the other developing country. It was also due to many taxpayers who did not reveal their wealth inside and outside the country also did not pay the taxes. Tax ratio in Indonesia is $11,89 \%$ in 2012, while Malaysia $15,6 \%$, Singapore $13,85 \%$, Philippines 12,89\%, and Thailand 15,45\% (Jefriando, 2016). Tax amnesty is also implemented for getting a new basic tax for increasing the tax ratio in Indonesia.

There is no prior study before in Indonesia about accounting perspective in tax amnesty. However, there are several studies in other countries. For example, the previous research about tax amnesty in the United States of America according to Buckwalter, Sharp, Wilde, \& Wood (2014) showed that "firms headquartered in states offering a tax amnesty program are more likely to begin engaging in a financial reporting irregularity during the amnesty period (page 4)." "Amnesty programs for tax-shelter investors have already proven to be successful in two states - California and New York - and would appear to be logical for states to put into place (page 62)." stated by Micheli (2005). Also, 9\% of the amount of the tax amnesty was invested in a fiveyear non-interest-bearing treasury certificate in Belgium (Luitel, 2014).

\section{Accounting Perspective}

Accounting perspectives is a peerreviewed forum with a focus on applied research and instructional cases with teaching notes (Laurin, 2011). Accounting perspective can be seen from the general accounting process, measurement, and reporting as well as disclosure, namely income statement, balance sheet, statement of changes in equity, and cash flow. Accounting measurement and disclosure rules have a significant impact on the real decisions that firms make, which is useful for the development of accounting standards (Kanodia \& Sapra, 2016). There is not sufficient data in using available the reporting and disclosures as the source about accounting perspective on the tax amnesty because this was a new program. However, the accounting perspective can be analyzed based on accounting practice, which includes accounting standards and government regulations. Therefore, this study explored standards and regulation for tax amnesty related to the measurement, the reporting, and the disclosure as the accounting perspective to see its relationship with the tax amnesty.

There are many changes in accounting and tax regulation. There are three accounting regulatory bodies in Indonesian taxation, Otoritas Jasa Keuangan (OJK), Finance Services Authority, Bank Indonesia, and Pusat Pembinaan Akuntan dan Jasa Penilai (PPAJP), Accounting and Appraisal Service (Santander, 2016). Bapepam is an agency for the control of capital markets and financial institutions, Bank Indonesia is an Indonesian Central Bank, and PPAJP is a unit under Ministry of Finance, Directorate for the supervision of accountants and chartered accountants (Santander, 2016). Furthermore, Santander (2016) explained that the accounting law was used are Law on capital markets (1995), Law on limited liability companies (1995) (PT Law), Law on company registration (1982), Regulation concerning company financial statements (1999), Banking Law (1992), and Law on the Central Bank (1999).

Accounting standard in Indonesian taxation is prepared and released by Dewan Standard Akuntansi Keuangan (DSAK), Financial Accounting Standards Board. Indonesian national Generally Accepted 
Accounting Principles (GAAP) comprises Pernyataan Standar Akuntansi Keuangan (PSAK), Indonesian Financial Accounting Standards (IFAS). PSAK is established based on the adoption of the International Financial Reporting Standards (IFRS) approach. IFRS is developed by International Accounting Standard Boards (IASB). The Indonesian Institute of Chartered Accountants (IAI) aimed to harmonize Indonesian standards (IFAS) with international standards IFRS/IAS since 1994 (Santander, 2016). According to Wild, Ken, Barbara, Winston, and Sundar (2013), the calendar year for the tax year is following the accounting (financial) year that should be published annually. Therefore, in the reporting of financial statements, Indonesian Financial Accounting Standards (IFAS) uses the same conceptual framework as IFRS. In analyzing the data, this study used IFRS's conceptual framework that is used as the reference by IFAS, as explained below.

According to IFRS (2001), the conceptual framework consists of three levels. The first level is the objective of financial statements. The second level is about the fundamental concepts that include qualitative characteristics and the elements. The third level is about the assumptions, principles, and constraints. It is vital to elaborate on the items in the second level of the conceptual framework, which are assets, liability, equity, income, and expenses. IFRS (2001) defines each of those elements as follow:

1. Assets: resources that are controlled by the entity as the result of past events and are expected to have economic inflow in the future (future economic benefits)

2. Liabilities: the current entity liabilities as of the effect of a past event and there will be economic outflow in the future

3. Equity: the residual value of the entity assets after being reduced by all entity liabilities

4. Income: the increasing of economic benefit in accountancy period or the increasing of assets or the decreasing of the liabilities resulted in the increasing of equity which is not related to the contribution from the owner's capital

5. Expense: the decreasing of economic benefit in accountancy period or the decreasing of assets or arising the liabilities resulted in the decreasing of equity which is not related to distribution to the owner's capital

In accounting, these five elements are divided into two parts, namely balance sheet and income statement, which consists of income and expenses. The balance sheet comprises of assets, liabilities, and equity, which are included in the accounting financial statements and taxation. The balance sheet applies the accounting equation, which is $\mathrm{A}=\mathrm{L}+\mathrm{E}$ ( $\mathrm{A}=\mathrm{Assets}$, $\mathrm{L}=$ Liabilities, and $\mathrm{E}=$ Equity). Therefore, the accounting perspective on tax amnesty would be based on accounting elements defined and explained in the accounting standards and related regulations.

\section{Research Method}

\section{The Data}

This study is qualitative research in the form of descriptive explorative analysis. The context in this study is information provided in the standards and regulations as well as the public perception, and the research journal. The period of data collection was from January 4, 2017, until April 10, 2017. The data source in this study was the subject of the data obtained (Arikunto, 2002). The data in this study included:

1. Financial Accounting Standard (PSAK 70)

2. Online News Media

3. Research Journal, including prior research

4. Accounting Discussion, based on Indonesian Institute of Chartered 
Accountants (IAI) and Observation and Research of Taxation (Ortax)

5. Government Policy (Undang-undang or Laws, Peraturan Menteri Keuangan or Ministry of Finance Decree, and Peraturan Direktur Jenderal Pajak or Director General of Taxes Circular Letter or)

This research focused on an accounting perspective towards tax amnesty and how far accounting influences tax amnesty. Meanwhile, the scope is in the application of accounting standard in taxation, especially in the tax amnesty.

\section{Data Collection Methods}

In order to get the information that is valid and reliable, the data collection method was the documentation. Documentation method means that the data is collected through the written heritage in the form of archives and includes books about the opinion of theories, arguments, or other books relating to the problems of investigation (Nawawi, 1991). According to Arikunto (2002), the documentation method is to find data such as notes, transcripts, books, newspapers, magazines, inscriptions, minutes of meetings, ledger, agenda, and so forth. This study used standards, regulations, research journals, and public perceptions of the documentation method. The expected outcomes from this documentation section can know and to find the valid data and evidence about the accounting elements in taxation, especially in the tax amnesty.

\section{Method of Data Analysis}

The method of analysis is a process to determine and compile the data systematically that is obtained from documentation result. By using this result, this study can conclude this research. Miles and Hubermen (1992) show that the activity in qualitative data analysis done interactively and comprehensively take place at every stage of the investigation continuously.

Data analysis is a process that breaks down the formal effort to find themes and formulate an idea as suggested and to provide assistance and the subject of the hypothesis (Bogdan and Taylor, 1975). Therefore, it can be concluded that data analysis is a process to organize and sort data into the pattern as based on data. According to Moleong (2002), data analysis is the process of arranging the order of the data; organize them into a pattern, categories, and basic description. That definition gives an overview of how vital the data analysis for research and reach research objectives.

The method of data analysis in this research is, according to Bungin (2003):

\section{Data Collection}

The collection of data is an integral part of the data analysis activities. A data collection activity in this research is to use the documentation. The documentation is to collect all of the data from accounting standards, online news media, research journal, accounting discussions, and government regulations.

\section{Data Reduction}

Data obtained from the report is quite a lot; therefore, it needs to be noted carefully and in detail. Data reduction means summarizing, selecting subject matter, focusing on important things, simplification, and transformation of raw data that is emerged from the written records in the field. Reducing the data collection is started by summarizing, encoding, searching themes, making groups, and writing memos to set aside the data that is not relevant. It is a need to reduce the data because this study is using a lot of data such as online news media that some contain invalid information and the sources cannot be indicated explicitly. Therefore, this step 
will sort out the data from invalid information.

\section{Display Data}

Display data is the description of a set of structured information that gives the possibility of drawing conclusions and taking action. The presentation may also form a brief description, the relationship between categories, matrices, charts, and tables. In this section, the analysis comes along with the inclusion of the results of the data.

\section{Conclusion Drawing and Verification}

Conclusion drawing and verification are the final activity of the data analysis. The conclusion is in the form of interpretation activities which is finding the meaning of the data that has been presented. The preliminary finding that is expressed is still provisional, and it will change if there is substantial evidence that supports the next stage founded. However, if the results that put forward in the early stages is supported by proof of valid and consistent when researchers is returned the spaciousness of the data collected, the findings presented a credible result.

After analyzing the data, the data are explained and interpreted in the form of words to describe the facts on the ground. The results of the data which is to answer the research questions are then extracted to be concluded. This study uses narrative description to present the result of the analysis.

\section{Analysis and Results}

The analysis of this study was based on the data collected, reduced, and displayed. The final displayed data is presented in Appendix 1. This study used the PSAK 70, Akuntansi Aset dan Liabilitas Pengampunan Pajak, Accounting for Tax
Amnesty Assets and Liabilities, an accounting standard established by IAI, as the basis for analyzing the data by focusing on the corporate financial statements. From the data analysis, this study found different accounting perspectives towards tax amnesty about the accounting patterns and procedures to tax amnesty, tax amnesty towards accounting perspective in the financial statement, and accounting dynamics contribution to a tax amnesty. The following section will further explain the findings based on these views.

\section{Accounting Patterns and Procedures to Tax Amnesty}

This study found two approaches related to accounting application for tax amnesty. The first accounting application uses the general approach from Pernyataan Standar Akuntansi Keuangan (PSAK) 70, Indonesia Financial Accounting Standards 70 to determine tax amnesty assets and liability. The second accounting application uses the optional approach under the particular provisions of the PSAK 70 (paragraphs 10-23). Finally, the differences between the general and optional method of the tax amnesty assets and liabilities are in the measurement, presentation, and disclosure.

Tax amnesty assets and liabilities are measured at fair values based on the self-assessment system. Individuals and business entities are allowed to re-measure the assets and liabilities of their fair value based on the requirements in IFAS as at the initial measurement of the Surat Keterangan Pengampunan Pajak (SKPP), Tax Amnesty Approval date. The optional approach measures the assets of tax amnesty based on the cost recorded in the SKPP. Meanwhile, for the liabilities of tax amnesty, it is measured by the number of cash or cash equivalents that will accomplish the contractual obligation related to the acquisition of the assets.

Mostly repatriated assets are recorded in cash and cash equivalents 
because it is not easy to repatriate stock or bond in a limited time. Additional assets that reveal in the Surat Pernyataan Harta untuk Pengampunan Pajak (SPHPP), Tax Amnesty Declaration Letter in the form of intangible assets cannot be amortized as well as the tangible assets that cannot be depreciated for tax purposes. All of the tax amnesty assets and liabilities are determined by Indonesian currency using nominal for cash and cash equivalents and fair value for cash. If the recorded tax amnesty assets and liabilities are using other currency, the nominal or fair value is determined using the exchange rate regulated by the Finance Minister.

The difference between tax amnesty assets and liabilities must be recorded as Additional Paid-in Capital (APIC) as part of the equity. The APIC will not be reclassified to retained earnings as well as profit or loss in the income statement based on the PSAK 70 paragraph 12. The difference between tax amnesty assets and liabilities is not classified as retained earnings because tax amnesty assets and liabilities arise from stockholders' contribution. The increasing or decreasing of the tax amnesty assets and liabilities are not included in the entity's income or expenses in a given period. However, it is managed as an equity transaction because it reflects the total cumulative of the entity performance.

The increasing or decreasing of the tax amnesty assets and liabilities that arise from the equity transaction is not presented in the retained earnings but the APIC. Peraturan Menteri Keuangan Republik Indonesia Nomor 119/PMK.08/2016 Pasal 2 ayat 3 (The Ministry of Finance Decree Number 119/PMK.08/2016 Paragraph 2 article 3) also stipulates that the additional tax amnesty assets and liabilities are reported or issued in the SPHPP, or SKPP treated as a new acquisition of assets and liabilities. In accounting, the new acquisition is stated as a transaction of owners. By this consideration, the difference between tax amnesty assets and liabilities is recognized as equity (the APIC not retained earnings). However in Undang-undang Nomor 11 Tahun 2016 Bab VII Pasal 14 ayat 1 (Law Number 11 the Year 2016 Chapter VII Paragraph 14 article 1) about the Taxation Treatment and Peraturan Menteri Keuangan Republik Indonesia Nomor 118/PMK.03/2016 Bab XXIII Pasal 45 ayat 1 (Ministry of Finance Decree Number 118/PMK.03/2016 Chapter XXIII Paragraph 45 article 1) about the obligation of the bookkeeping implementation and the depreciation of the asset treatment, the difference arises from tax amnesty assets and liabilities recorded as retained earnings. The difference in the rules showed the discrepancies between assets and liabilities direct people to choose the policy based on either PSAK or PMK.

It seems that the difference does not give any effect because the difference lies in the classification of the account. However, both have the same position in equity. Equity consists of three types, namely ordinary or preference shares, additional paid-in capital (APIC), and retained earnings. The tax treatment is different based on the kind. By recording the difference between assets and liabilities in the additional paid-in capital, it means that it cannot be distributed to the stockholders as dividends. This additional paid-in capital in the Undang-undang Republik Indonesia Nomor 36 Tahun 2008 Pasal 4 ayat 3 huruf c (Law Number 36 the Year 2008 Paragraph 4 article 3 letter c) about Income Taxes is not an object of corporate income taxes according to Direktorat Jenderal Pajak (2008).

By grouping the difference arises between assets and liabilities in the retained earnings, the retained earnings can be distributed to the stockholders in the form of a dividend. Retained earnings are not an object of corporate income tax because they are already taxed at the time as the profit of the current year. Retained earnings are included in an object of corporate income taxes if distributed to the stockholders as dividends to a specific condition. 
The redemption money was charged to the income statement directly when the SKPP was received. The balance amount in the income statement should be adjusted when the SKPP was received. The accounts that should be adjusted in balance amount are for example interest and fines. After adjusting, the next procedure is to write off the differences. The cases of the accounts that should be written off related to tax disputes are tax refunds, deferred tax, and provision for uncertain tax positions.

The measurement of assets declared in the Surat Pernyataan Harta untuk Pengampunan Pajak (SPHPP), Tax Amnesty Declaration Letter should comply with IFAS. For example, building as an asset is included in the fixed asset according to the PSAK 16 about the acquisition costs using the revaluation method (fair value) or cost method (historical cost). There are additional things to do if the entity has control over an investee. The entity should re-measure the assets and liabilities as at the SKPP. The necessary re-measurement should comply with the PSAK 22 (about Business Combination) or PSAK 38 (about Business Combination of Entities under Common Control). The consolidation procedures accordance with PSAK 65 (about Consolidated Financial Statements) should be applied after the re-measurement done. The infestations to the subsidiary are recorded using the cost method during the re-measurement when the period of the SKPP date is made.

After the measurement process, the entity should provide proper presentation and disclosure in the financial statements that are presented separately. If the remeasurement is applied, the entity should reclassify out the tax amnesty assets and liabilities items then present together with the similar assets or liabilities. After that, the entity should represent the previous financial statements if the date is submitted after the SKPP date. There are at least three minimum standards as the requirements in presenting the financial statements, namely the SKPP date, the amount of tax amnesty assets based on the SKPP, and an amount of tax amnesty liabilities. There are also two types of transitional provisions. If the business entities use the general approach, they must apply the provisions of the PSAK 25 (paragraphs 41-53) about accounting policies, change in estimates and errors. Also, if the business entities decide to use an optional approach, they are not required to apply the provisions that are prospective and restatement the prior period of the financial statements.

The difference in the regulation stated by DSAK-IAI and UU/PMK showed ambiguity. Conceptually the implementation of tax amnesty through the PSAK 70 revealed potential weak measurement validity. The PSAK 70 regulates specific corporates. Furthermore, there is also possible political intervention and organizational dynamics that might influence the accounting standard. Therefore, this regulation should be adjusted in order to make it more relevant and transparent to be applied for all of the taxpayers; individuals, business entities, and Usaha Mikro Kecil dan Menengah (UMKM), Micro, Small, Medium Enterprises.

\section{Accounting Perspective on Tax Amnesty in Financial Statement Presentation}

In the development of business, there is a need to present the corporate financial statement to the public for the purpose of attracting investors. There are many changes and improvements in taxation laws as the standard for relevant, reliable, and fair financial statement information. Furthermore, in some parts, there are accounting approach differences between accounting for tax amnesty and financial accounting standard. Therefore, to give relevant, reliable, and fair financial statement information and not to cause misunderstanding, individuals, as well as business entities, can present their financial statement accordance with the financial 
accounting standard which is called commercial report.

For tax purposes, there should be a fiscal correction of the existing temporary differences which is called fiscal report as reconciliation. Reconciliations in each country are different because of the different approaches and standard. At European Union (EU) level, reconciliation of relationships between accounting and taxation in relation to IFRS is challenging because there is no universal fiscal standard and no fiscal consolidation for groups (Ristea, 2009). In addition, fiscal corrections also need some financial statement notes about the differences that arise. The records of fiscal financial statements approach come as the solution for accounting and taxation according to OECD (2016) which includes:

1. Tax provisions are dominant with accounting practices

2. Tax provisions for the purpose of preparing the financial statements is a separate independent standard of accounting principles

3. Tax provisions are inset on accounting standards

From the OECD's fiscal, financial statements note, it can be inferred that accounting gives effect to the taxation. Accounting influences the taxation constitution in Indonesia proven by the laws. Moreover, Indonesia has a specific accounting standard for tax amnesty. From an organizational point of view, accounting is considered a component of fiscal management, offering information that assures efficient, correct and secure taxation function (Strapuc \& Cazacu, 2016). Accounting and taxation are related to each other in many ways. For example, in the tax management, to pay efficient taxes and minimize tax payable can use legal manner through accounting gaps. Tax management comprises tax planning, tax implementation, and tax control.

Similar to the relation of taxation and accounting, the application of tax amnesty influence the financial statement, especially in the accounting perspective. "These additional tax amnesties generate less short-run revenue than predecessors and tend to magnify revenue losses associated with disincentives for long-run tax compliance (Luitel \& Sobel, 2007 page 19)." For example, after the corporates join tax amnesty, companies will get additional funds in the form of offshore assets and investments (stocks or bonds). Accordingly, they will pay ransom for offshore assets that will be repatriated, and this will be applied once in the form of final income tax. However, for the investments (stocks or bonds), this will be applied continuously for a minimum period of three years. From the stocks, the stockholders can get the dividends whereas, from the bonds, the stockholders can get interested coupons that will have an impact in yearly corporate income tax return. In this calculation, taxpayers will apply accounting formula to get the proper dividends or interest coupons which will help them gain a premium of discount amortization.

\section{Accounting Dynamics Contribution to Tax Amnesty}

This study focused on accounting dynamics by reviewing public perception on accounting role in tax amnesty. The public opinion was obtained from the news, which is included online news media, as the proxy of public perception. The online news media about tax amnesty in Indonesia mostly published information concerning tax amnesty (Appendix 1). All of the online news data come from trusted sources such as BBC Indonesia, The Jakarta Post, Jakarta Globe, and Metro TV. The data showed that there was no mention of accounting contribution in the tax amnesty program. It means that accounting was not perceived as of significant in the program as published in the online news media.

The different data set, such as accounting standard, journals, prior research, accounting discussion, and policy, 
have described a concern in perceived the accounting role (Appendix 1). It is not easy to see the accounting pattern in some of the data because it is not explicitly mentioned. The accounting pattern in some of the policy data, such as law, the regulation of Finance Minister, and the regulation of Director General of Taxes was implicitly mentioned. They were not directly mentioned accounting contribution to tax amnesty, but it is stated the importance of reports for the program. Therefore, it could be assumed that accounting contribution to tax amnesty is established by indicating accounting treatment for assets and liabilities related to tax amnesty, particularly for the corporation.

Based on Hines (1988), where accounting is regarded as a social construction, this study believes that accounting plays a vital role in the tax amnesty program. As a social construction, accounting becomes a means of how information is delivered appropriately through the reporting form. Thus, accounting as social construction was had the purpose of giving information, some words such as reports, conveys, attaches, and presents are including in accounting. There are the following regulations regarding the tax amnesty program. The subsequent rule is based on the Undangundang (Laws), Peraturan Menteri Keuangan (Ministry of Finance Decree), and Peraturan Direktur Jenderal Pajak (Director General of Taxes Circular Letter).

In conclusion, the accounting perspective towards tax amnesty, based on the conceptual framework related to the element of financial statements, assets, liabilities, and equity that also used in the tax amnesty. This finding related to the existence of the accounting elements in tax amnesty, particularly for a business entity. The critical point to see the items of the conceptual framework is the balance sheet. The application of tax amnesty is also affecting the additional revenues or revenues losses for calculating the corporate income tax.

\section{Conclusions}

This study aimed to understand the accounting perspectives of tax amnesty program implemented in Indonesia. This study analyzed and reviewed the accounting in Indonesia as an essential part of the tax amnesty program. The findings of this study answered the purpose of the study, as explained in the introduction, which is the following:

1. There are two options for recognizing the tax amnesty assets and liabilities, which are general accounting approach and optional accounting approach. The similarity between the options is under the regulation of Indonesia standards body-setting. The differences are general accounting approach under the Indonesia Financial Accounting Standards Board (DSAK) and optional accounting approach under the specific provisions of the PSAK 70.

2. The elements of accounting which are assets, liabilities, and equity are included in tax amnesty

Accounting has a relationship with tax amnesty. It can be seen from some part of the element in the conceptual framework that is included in tax amnesty in the form of assets, liabilities, and equity. The assets that come as the additional assets must be measured as the acquisition cost. Whereas, the liabilities that occur as the accomplishment of the contractual obligation from assets acquisition must be measured as cash or cash equivalent. Then, the difference between tax amnesty assets and liabilities that are mentioned in the accounting equation emerge as the equity $(\mathrm{A}=\mathrm{L}+\mathrm{E})$.

3. Different regulation between PSAK 70 with UU and PMK 118

In the PSAK 70, the difference between assets and liabilities is recorded in the equity as Additional Paid-in Capital (APIC), and will not be reclassified in retained earnings or 
profit or loss in the income statement. While in UU and PMK 118, the difference between assets and liabilities is recorded in the equity as retained earnings. This difference regulation shows that there is no continuity between the Indonesian Financial Standards Board (DSAK-IAI) with the laws and the regulation of Finance Minister. This is also can make the corporate choose using the regulation under PSAK 70 or the regulation under Indonesian laws.

4. Mandatory approach

There must be re-measurement of tax amnesty assets and liabilities as recorded in the SKPP if the entity has controlled over an investee. The necessary re-measurement can comply either with the PSAK 22 about Business Combination or with the PSAK 38 about Business Combination of Entities under Common Control. After the re-measurement, the entity should apply the consolidation procedure stated in the PSAK 65 about Consolidated Financial Statements.

There is a limitation to this study. This study sees public opinion about tax amnesty. From this point of view, the accounting dynamics contribution is focused on the accounting perception stated in online news media. Therefore, the scope is the application of tax amnesty, as indicated in the online news media. The extent and focus of this study are limited because it has not yet analyzed the application of tax amnesty in the financial reporting statements. This limitation is also because the tax amnesty program is still considered a new program which recently ended on March 31, 2017.

The tax amnesty program was raised a successful result from this one-year application. According to Direktorat Jenderal Pajak (2017), the realization of the declared assets was surprisingly gaining total $\mathrm{Rp} 4,523 \mathrm{~T}$ (domestic $\mathrm{Rp} 3,495 \mathrm{~T}$, overseas $\mathrm{Rp} 1,028 \mathrm{~T}$ ) from the total target
Rp4,000 T. The achievement of the repatriations was gaining Rp146 $\mathrm{T}$ from the target Rp1,000 T. The redemption money slightly missed the goal, Rp123.64 T out of Rp165 T. Although the repatriation and the redemption money were not met the goal, it exceeds expectations for the declared assets. This is such a big success for Indonesia and needs more investigation. Therefore, further study should also compare the listed companies mostly participate in the regulation of Indonesia Financial Standards Board (DSAK-IAI) or the regulation of Indonesian laws. From that comparison, an analysis of the impact of choosing one regulation over another to Indonesian taxation should also be conducted.

\section{References} "Belajar Pajak." Kementerian Keuangan. Jakarta, 2012.

Aliandu, Kunradus. "Ekonomi Dunia Melambat, Banyak Negara Terapkan Tax Amnesty." Investor Daily, June 21, 2016. Accessed September 17, 2016. http://www.beritasatu.com/ekonom i/370953-ekonomi-duniamelambat-banyak-negara-terapkantax-amnesty.html.

Amindoni, Ayomi. "Govt Records Rp 500 Trillion Assets in Tax Amnesty Program." The Jakarta Post, September 15, 2016. Accessed September 17, 2016. http://www.thejakartapost.com/ne ws/2016/09/15/govt-records-rp500-trillion-assets-in-tax-amnestyprogram.html.

Amindoni, Ayomi. "Indonesia Probes 272 Taxpayers Mentioned in Panama Papers." The Jakarta Post, May 12, 2016. Accessed September 27, 2016. http://www.thejakartapost.com/new s/2016/05/12/indonesia-probes- 
272-taxpayers-mentioned-inpanama-papers.html.

Arikunto, Suharsimi. "Prosedur Penelitian Suatu Pendekatan Praktek." V Edition. Jakarta: PT. Rineka Cipta, 2002.

BBC Indonesia. "DPR Sahkan UndangUndang Tax Amnesty." BBC Indonesia, June 28, 2016. Accessed October 20, 2016. http://www.bbc.com/indonesia/beri ta_indonesia/2016/06/160628_indo nesia_dpr_tax_amnesty.

Bogdan and Taylor, 1975 in J. Moleong, Lexy. "Metodologi Penelitian Kualitatif." Bandung: Remadja Karya, 1989.

Buckwalter, Neal. D., Sharp, Nathan. Y., Wilde, Jaron. H., \& Wood, David. A. "Are State Tax Amnesty Programs Associated with Financial Reporting Irregularities?" Public Finance Review 42, no. 6 (2014): 774-799. Accessed October 15, 2016.

DOI:10.1177/1091142113499397.

Bungin, Burhan. "Analisis Data Penelitian Kualitatif." Jakarta: PT Raja Grafindo Persada, 2003.

Center for Indonesia Taxation Analysis (CITA). 2016. Center for Indonesia Taxation Analysis. Accessed January 24, 2017. http://www.cita.or.id/.

Direktorat Jenderal Pajak. "Amnesti Pajak." Kementerian Keuangan. Jakarta, 2016.

Direktorat Jenderal Pajak. "Amnesti Pajak." Kementerian Keuangan. Jakarta, 2017.

Direktorat Jenderal Pajak. 2008. Undangundang Republik Indonesia Nomor 36 Tahun 2008. Accessed April 9, 2017.

http://www.jdih.kemenkeu.go.id/fu 11Text/2008/36TAHUN2008UU.H TM

Fajriah, Lily Rusna. "Jauh Dari Target, Uang Tebusan Tax Amnesty Baru Rp3,12 Triliun." Sindonews,
September 1, 2016. Accessed October 13, 2016. http://ekbis.sindonews.com/read/11 35770/33/jauh-dari-target-uangtebusan-tax-amnesty-baru-rp3-12triliun-1472700961.

Hines, Ruth D. 1988. "Financial Accounting: In Communicating Reality, We Construct Reality." Accounting, Organizations and Society volume 13, no. issue 3: 251261,

http://www.sciencedirect.com/scien ce/article/pii/0361368288900037.

IFRS Global Standards for The World Economy. 2001. Conceptual Framework. Last modified 2017. http://www.ifrs.org/Current-

Projects/IASB-

Projects/Conceptual-

Framework/Pages/ConceptualFramework-Summary.aspx.

Indrawan, Aditya Fajar. "Luhur Beberkan Pihak Pembuat Konsep Tax Amnesty Indonesia." Detik Finance, July 20, 2016. Accessed January 24, 2017.

http://finance.detik.com/ekonomibisnis/3257352/luhut-beberkanpihak-pembuat-konsep-taxamnesty-indonesia.

Jefriando, Maikel. "Sri Mulyani: Kekayaan WNI Di Luar Negeri Rp 3.250 T, Rp 2.600 T Di Singapura." Detik Finance, September 20, 2016. Accessed September 27, 2016. http://finance.detik.com/beritaekonomi-bisnis/d-3302486/srimulyani-kekayaan-wni-di-luarnegeri-rp-3250-t-rp-2600-t-disingapura.

Kanodia, C., \& Sapra, H. (2016). A Real Effects Perspective to Accounting Measurement and Disclosure: Implications and Insights for Future Research. Journal of Accounting Research, 54(2), 623-676. doi:10.1111/1475-679X.12109.

Katawarta. 2016. "Sejarah Kebijakan Tax Amnesty di Indonesia." Katawarta. 
Accessed January 23, 2017. http://www.katawarta.com/hukumdan-kriminalitas/sejarah-kebijakantax-amnesty-di-indonesia.

Laurin, Claude. "Accounting Perspectives (AP)." The Canadian Academic Accounting Association. N.p., 2011. Web. 27 Sept. 2016.

Luitel, H. S., \& Sobel, R. S. (2007). The Revenue Impact of Repeated Tax Amnesties. Public Budgeting \& Finance, 27(3), 19-38. doi:10.1111/j.15405850.2007.00881.x

Luitel, Hari S. 2014. "Is Tax Amnesty a Good Tax Policy: Evidence from State Tax Amnesty Program" Lanham, MD, United States: Lexington Books.

Maskur, Fatkhul. "Pengampunan Pajak: 38 Negara Sudah Terapkan Tax Amnesty." Bisnis, September 1, 2016. Accessed September 17, 2016. http://finansial.bisnis.com/read/201 60901/10/580310/pengampunanpajak-38-negara-sudah-terapkantax-amnesty.

Merah Putih Bisnis. "Alasan Orang Kaya Simpan Kekayaan Di Luar Negeri." Merah Putih Bisnis, April 5, 2015. Accessed September 27, 2016. http://news.merahputih.com/keuan gan/2016/04/05/alasan-orang-kayasimpan-kekayaan-di-luarnegeri/39973/.

Micheli, Chris. "California Enacts Tax Amnesty Program for Personal, Corporate and Sales Taxes." Journal of State Taxation 23, no. 3 (2005): 25-64.

Miles, M. B. and Huberman, A. M. "Qualitative Data Analysis: A Sourcebook of New Methods." Beverly Hills: Sage, 1992.

Moleong, Lexy. "Metodologi Penelitian Kualitatif." Bandung: PT. Remaja Rosdakarya, 2002.

Nawawi, Hadari. "Metodologi Penelitian Bidang Sosial." Yogyakarta: Gajah Mada University Press, 1991.
Observation \& Research of Taxation (Ortax). 2016. "Amnesti Bisa Dongkrak Rasio Pajak Menjadi 14\%." Ortax. Accessed January 23, 2017.

http://www.ortax.org/ortax/?mod= berita\&page $=$ show $\& \mathrm{id}=15214 \& \mathrm{q}=$ \&hlm=.

Organization for Economic Co-operation and Development (OECD). "Accounting and Taxation." France, 2016.

Prasetiyo, Bagus. "Rp 11.400 Triliun Uang Indonesia 'Menginap' Di Luar Negeri." Tempo, April 5, 2016. Accessed September 27, 2016. https://m.tempo.co/read/news/2016 /04/05/090759950/rp-11-400triliun-uang-indonesia-menginapdi-luar-negeri.

Ristea, M. "The Relationship between Accounting and Taxation." In Proceedings of 2009 Debate organized by CECCAR in partnership with The International Fiscal Association, June 20, 2009. Romania: CECCAR, 2009.

Santander, Banco. "Indonesian Tax System." Santander Trade Portal. Export Entreprises S.A., Sept. 2016. Web. 29 Sept. 2016.

Sawitri, Angelina Anjar. "Sri Mulyani: Target Penerimaan Tax Amnesty Tetap Rp 165 T." Tempo, August 5, 2016. Accessed October 12, 2016. https://m.tempo.co/read/news $/ 2016$ /08/05/092793604/sri-mulyanitarget-penerimaan-tax-amnestytetap-rp-165-t.

Simbolon, Bob H. "Dirjen Pajak Akui Luhut Pandjaitan Pencetus Tax Amnesty." Satu Harapan, September 23, 2016. Accessed January 24, 2017. http://www.satuharapan.com/readdetail/read/dirjen-pajak-akui-luhutpandjaitan-pencetus-tax-amnesty.

Strapuc, Constantin, \& Cazacu, Nicolaie. "Interaction between Accounting and Taxation - Temporal and 
Spatial Milestones." The USV Annals of Economics \& Public Administration 16, no. 1 (2016): 199-205.

The Jakarta Post. "Singaporean Banks Block Tax Amnesty." The Jakarta Post, September 16, 2016. Accessed
September $\quad 17, \quad 2016$. http://www.thejakartapost.com/ne ws/2016/09/16/singaporean-banksblock-tax-amnesty.html.

Wild, John J., Ken W. Shaw, Barbara Chiappetta, Winston Kwok, and Sundar Venkatesh. 